\title{
IMPLEMENTASI KEBIJAKAN PROGRAM AGROPOLITAN DI PROVINSI KEPULAUAN BANGKA BELITUNG
}

\author{
Rully Redhani, Bambang Ari Satria \\ Sekolah Tinggi Ilmu Sosial dan Ilmu Politik Pahlawan 12 Sungailiat
}

Coressponding Author, email : bambang.ari.satria@stisipolp12.ac.id

\begin{abstract}
Abstrak
Dalam pengembangan sektor pertanian, potensi yang dimiliki Provinsi Kepulauan Bangka Belitung sebagai kawasan pertanian telah ditetapkan dalam Rencana Tata Ruang Wilayah (RTRW) Provinsi Kepulauan Bangka Belitung Tahun 2014-2034. Penelitian ini berjudul Implementasi Program Agropolitan di Provinsi Kepulauan Bangka Belitung. Tujuan penelitian ini adalah untuk mengetahui bagaimana implementasi program agropolitan di Bangka Belitung dan mengidentifikasi faktor pendukung program agropolitan di Bangka Belitung. Manfaat penelitian ini dapat memberikan wawasan dan sumbangan pemikiran bagi perkembangan ilmu administrasi negara khususnya kebijakan publik yaitu pada implementasi kebijakan. Penelitian ini menggunakan metode penelitian kualitatif. Teknik pengumpulan data menggunakan wawancara, observasi dan dokumentasi. Hasil penelitian menunjukkan bahwa implementasi kebijakan program agropolitan di Provinsi Kepulauan Bangka Belitung sudah berjalan dengan baik. Hal ini ditandai dengan komunikasi yang dijalankan pelaksana kebijakan sangat jelas. Rekomendasi yang diberikan adalah memberikan pemahaman kepada aparatur pelaksana dan para petani agar dapat mengikuti tahapan-tahapan program agropolitan dengan menerapkan standar operasional prosedur yang ada, mulai dari dilakukan sosialisasi, workshop ataupun pelatihan-pelatihan penerapan SOP yang benar.
\end{abstract}

Kata Kunci: Kebijakan; Implementasi; Program Agropolitan.

\begin{abstract}
In developing the agricultural sector, the potential of the Bangka Belitung Islands Province as an agricultural area has been stipulated in the Regional Spatial Plan (RTRW) of the Province of Bangka Belitung Islands for 2014-2034. This research is entitled Implementation of Agropolitan Program in Bangka Belitung Islands Province. The purpose of this study was to determine how to implement agropolitan programs in Bangka Belitung and to identify supporting factors for agropolitan programs in Bangka Belitung. The benefits of this research can provide insight and contribution of thought to the development of state administration science, especially public policy, namely on policy implementation. This study used qualitative research methods. Data collection techniques using interviews, observation and documentation. The results showed that the implementation of the agropolitan program policy in the Province of Bangka Belitung Islands had gone well. This is indicated by very clear communication carried out by the policy implementer. The recommendation given is to provide understanding to the implementing apparatus and farmers so that they can follow the stages of the agropolitan program by applying the existing standard operating procedures, starting from conducting socialization, workshops or training on the correct application of SOPs.
\end{abstract}

Keywords: Policy; Implementation; Agropolitan Program. 
Jurnal Administrasi Negara

ISSN : 2598-4039 (Online)

ISSN : 2302-2231 (Print)
Rully Redhiani, Bambang Ari Satria,

Sekolah Tinggi Ilmu Sosial dan Ilmu Politik

Pahlawan 12 Sungailiat

\section{PENDAHULUAN}

Pembangunan pertanian di Provinsi Kepulauan Bangka Belitung sangat menentukan dalam peningkatan produksi hasil pertanian, pencapaian kedaulatan pangan, peningkatan mutu, daya saing dan nilai tambah hasil, peningkatan pendapatan petani serta menjadi penarik bagi pertumbuhan industri hulu dan pendorong pertumbuhan industri hilir yang kontribusinya pada pertumbuhan ekonomi daerah cukup besar yang pada akhirnya akan meningkatkan pendapatan daerah. Salah satu implementasi program Pemerintah Provinsi Kepulauan Bangka Belitung dalam pembangunan berbasis pertanian adalah program agropolitan. Agropolitan adalah hasil pendekatan terhadap teoriteori pembangunan yang berbasis pada sektor pertanian atau pembangunan wilayah pertanian (Nugroho, 2009). Pertanian harus di dorong pertumbuhannya melalui kebijakan yang diformulasikan secara tepat. Kebijakan pembangunan pertanian ditujukan untuk meningkatkan ketahanan pangan, mengembangkan agribisnis dan meningkatkan kesejahteraan petani (Baiq Diana, dkk : 2016). Dengan demikian, produk pertanian yang akan dihasilkan memenuhi syarat secara kualitas, kuantitas dan keberlanjutan sehingga memiliki daya saing.

Konsep dasar pengembangan kawasan agropolitan adalah sebagai upaya menciptakan pembangunan interregional secara berimbang. Artinya untuk meningkatkan keterkaitan pembangunan kota dengan desa melalui pengembangan kawasan perdesaan yang terintegrasi dalam sistem perkotaan (A. T. Basuki, 2012). Dalam upaya mengembangkan kawasan agropolitan menyeluruh, terintegrasi, dan berkelanjutan diperlukan pengembangan kawasan agropolitan di Provinsi Kepulauan Bangka Belitung.

Konsep pengembangan agropolitan juga dapat diinterprestasikan sebagai "teority-based identities". Konsep kawasan pedesaan ini menyangkut potensi, kemandirian dan kebanggaan lokal. Agropolitan mempunyai prinsip pemberdayaan yang harus diterapkan dalam mengembangkan kawasan agropolitan yaitu: prinsip kerakyatan, pembangunan diutamakan bagi kesejahteraan rakyat, bukan kesejahteraan orang per orang atau kelompok. Prinsip swadaya, bimbingan dan dukungan kemudahan (fasilitas) yang diberikan harus mampu menumbuhkan keswadayaan dan kemandirian, bukan menumbuhkan ketergantungan. Prinsip kemitraan, memperlakukan pelaku agrobisnis sebagai mitra kerja pembangunan yang berperan serta dalam seluruh proses pengambilan keputusan dan menjadikan mereka sebagai pelaku dan mitra kerja 
Jurnal Administrasi Negara

ISSN : 2598-4039 (Online)

ISSN : 2302-2231 (Print)
Rully Redhiani, Bambang Ari Satria,

Sekolah Tinggi Ilmu Sosial dan Ilmu Politik

Pahlawan 12 Sungailiat yang aktif dalam melaksanakan kegiatan pembangunan. Prinsip bertahap dan berkelanjutan, pembangunan dilaksanakan sesuai dengan potensi dan kemampuan masyarakat setempat serta memperhatikan kelestarian lingkungan.

Program agropolitan ini adalah sesuatu yang memanfaatkan kawasan perdesaan dengan basis pertanian secara luas dimulai pada perkebunan, pertanian, peternakan dan kehutanan, dimana hal ini untuk kemajuan perdesaan dan perkembangan perekonomian masyarakat perdesaan untuk kemajuan (R. N. Putra, 2015). Pada dasarnya pelaksanaan program agropolitan dipandang sebagai alternatif model pembangunan yang sangat menjanjikan. Pelaksanaan agropolitan ini justru akan mengatasi ketidakseimbangan antara perkotaan dan perdesaan, hal ini dikarenakan agropolitan merupakan suatu model yang mengandalkan desentralisasi, mengandalkan infrastruktur setara kota di wilayah perdesaan, sehingga mendorong urbanisasi (Mahardhani, Ardhana Januar, 2013). Menurut Farhanah dan Prajanti (2015) konsep agropolitan diperlukan bagi negaranegara agraris seperti Indonesia. Konsep agropolitan pertama kali diperkenalkan oleh Mc.Douglass dan Friedmann sebagai strategi untuk pembangunan kawasan pedesaan.

Pengembangan peruntukkan pertanian di Bangka Belitung dilakukan melalui penetapan kawasan peruntukkan pertanian pangan berkelanjutan melalui intensifikasi dan ekstensifikasi kawasan pertanian berkelanjutan. Penetapan kawasan peruntukkan pertanian seluas $903.450 \mathrm{Ha}$ yang terdiri dari 355.453 Ha untuk kawasan pertanian tanaman pangan, 221.512 Ha untuk kawasan pertanian hortikultura dan 316.385 Ha untuk kawasan perkebunan. Selama ini ketika panen, petani dihadapkan pada situasi tanpa pilihan kecuali menjual komoditi hasil panennya kepada para pedagang tengkulak, dan ketika itu harga hasil komoditi cenderung turun. Harga dasar yang ditetapkan pemerintah atas suatu komoditi dalam praktiknya terdistorsi di tingkat pasar dan tidak optimal memberikan manfaat kepada para petani.

Visi besar Gubernur Provinsi Kepulauan Bangka Belitung dalam pembangunan daerah adalah Babel sejahtera, provinsi maju yang unggul di bidang inovasi, agropolitan dan bahari dengan tata kelola pemerintahan dan pelayanan publik yang efisien dan cepat berbasis teknologi. Salah satu misinya adalah meningkatkan pembangunan ekonomi berbasis potensi daerah. Adapun program untuk meningkatan pembangunan ekonomi masyarakat berbasis potensi daerah melalui program agropolitan. Program unggulan 
Jurnal Administrasi Negara

ISSN : 2598-4039 (Online)

ISSN : 2302-2231 (Print)
Rully Redhiani, Bambang Ari Satria,

Sekolah Tinggi Ilmu Sosial dan Ilmu Politik

Pahlawan 12 Sungailiat agropolitan meliputi memperluas lahan produksi lada di Bangka Belitung dalam rangka mengembalikan lada sebagai produk agrobisnis andalan Bangka Belitung sehingga kejayaan Babel sebagai Provinsi Lada bisa dicapai kembali, membangun pusat penelitian dan pengembangan rekayasa lada maupun produk perkebunan lainnya seperti karet dan sawit di Provinsi Bangka Belitung, memberikan pelatihan agrobisnis profesional kepada petani-petani di Bangka Belitung sehingga petani mampu memproduksi produk pertanian dengan kualitas unggul dan memberikan bantuan bibit dan sarana pendukung pengembangan agrobisnis lainnya agar petani memperoleh hasil optimal.

\section{Implementasi}

merupakan

persamaan fungsi dari kebijakan, formator, implementor, inisiator, dan waktu (Akib, 2010). Penekanan utama fungsi ini adalah kepada kebijakan itu sendiri, kemudian hasil yang dicapai dan dilaksanakan oleh implementor dalam kurun waktu tertentu. Implementasi kebijakan menghubungkan antara tujuan kebijakan dan realisasinya dengan hasil kegiatan pemerintah. Dalam implementasi kebijakan terdapat pihak implementor dan kelompok sasaran. Implementor kebijakan adalah mereka yang secara resmi diakui sebagai individu/lembaga yang bertanggung jawab atas pelaksanaan program di lapangan. Kelompok sasaran adalah para pihak yang dijadikan sebagai objek kebijakan. Menurut Lester dan Stewart (dalam Kusumanegara, 2010) implementasi adalah sebuah tahapan yang dilakukan setelah aturan hukum ditetapkan dan implementasi merupakan bagian dari proses administrasi yang menunjukkan desain atau pelaksanaan sistem administrasi yang mempunyai konsekuensi terhadap pelaksanaan, isi dan dampak suatu kebijakan.

Keterkaitan

implementasi kebijakan program agropolitan dengan rumpun ilmu administrasi publik adalah sebagai produk kebijakan. Adapun tahapan implementasi kebijakan program agropolitan terdapat empat aspek yang menjadi acuan dalam menganalisis implementasi kebijakan program agropolitan di Kepulauan Bangka Belitung, yaitu : komunikasi, disposisi, sumber daya, dan struktur birokrasi. Berdasarkan hal tersebut, peneliti memandang perlu untuk melakukan penelitian dengan judul "Implementasi Kebijakan Program Agropolitan di Provinsi Kepulauan Bangka Belitung". Penelitian ini diharapkan dapat memberikan wawasan dan gambaran bagi kalangan pemerintah dan stakeholders yang terlibat pada pelaksanaan program agropolitan tentang implementasi kebijakan tersebut. Secara teoritis, hasil penelitian diharapkan dapat memberikan wawasan dan sumbangan pemikiran bagi 
Jurnal Administrasi Negara

ISSN : 2598-4039 (Online)

ISSN : 2302-2231 (Print)
Rully Redhiani, Bambang Ari Satria,

Sekolah Tinggi Ilmu Sosial dan Ilmu Politik

Pahlawan 12 Sungailiat perkembangan Ilmu Administrasi Negara khususnya Kebijakan Publik yaitu pada implementasi kebijakan.

\section{METODE PENELITIAN}

Jenis penelitian yang digunakan peneliti dalam penelitian ini adalah penelitian kualitatif. Menurut Sugiyono (2012), di dalam penelitian kualitatif batasan masalah disebut dengan fokus penelitian yang berisi pokok-pokok masalah yang masih bersifat umum. Penelitian ini adalah penelitian yang fokus membahas bagaimana implementasi kebijakan program agropolitan. Jenis data yang digunakan dalam penelitian ini adalah data primer dan data sekunder. Data primer dalam penelitian ini diperoleh dari hasil observasi, dokumentasi dan wawancara. Dalam penelitian ini, informan yang diwawancarai adalah Gubernur Provinsi Kepulauan Babel, Kepala Dinas Pertanian Provinsi Babel, Ketua Koperasi Lada Babel, Petani Babel dan Akademisi UBB. Sementara, data sekundernya adalah dokumen pendukung yang berkaitan dengan Implementasi Kebijakan Program Agropolitan di Babel. Teknik analisis data yang digunakan dalam penelitian terdiri dari pengorganisasian dan persiapan data, yaitu kegiatan menyalin, menyortir dan mengatur data ke dalam berbagai jenis yang tergantung pada sumber informasi. Metode analisa data yang digunakan peneliti yaitu :

1) Membaca seluruh data, untuk memahami keseluruhan data

2) Pengkodean atau kategorisasi data, yaitu menganalisis secara rinci data dan informasi yang ada dengan proses coding.

3) Menentukan deskripsi atau gambaran umum

4) Interrelasi, yaitu merepresentasikan gambaran umum kedalam narasi kualitatif untuk menyampaikan temuan analisis

5) Interpretasi makna, yaitu menangkap esensi dari informasi yang ada lalu melakukan interpretasi baik berdasarkan pandangan informan secara subjektif, atau dengan membandingkan temuan yang diperoleh dengan literatur atau teoriteori ada.

Lokasi penelitian adalah Provinsi Kepulauan Bangka Belitung. Pemilihan lokasi penelitian ini didasarkan karena program agropolitan yang ada di Provinsi Kepulauan Bangka Belitung.

\section{HASIL DAN PEMBAHASAN}

Perkembangan Produksi dan Luas Lahan Lada Putih di Provinsi Kepulauan Bangka Belitung

Komoditas lada putih di Provinsi Kepulauan Bangka Belitung memiliki potensi dan kekuatan dari banyak aspek, baik sosial, teknologi, ekonomi, maupun lingkungan. Produksi lada 
Jurnal Administrasi Negara

ISSN : 2598-4039 (Online)

ISSN : 2302-2231 (Print)
Rully Redhiani, Bambang Ari Satria,

Sekolah Tinggi Ilmu Sosial dan Ilmu Politik

Pahlawan 12 Sungailiat putih di Bangka Belitung mengalami dinamika produksi yang cukup signifikan di era penambangan timah inkonvensional (TI) yang berdampak kepada penurunan jumlah luas lahan dan produksi lada. Saat ini banyak petani mulai kembali berkebun lada seiring dengan harga lada yang tinggi di pasar internasional. Hal ini perlu disikapi dengan hati-hati karena pengaruh ketersediaan lada di pasar internasional sangat mempengaruhi harga internasional dan harga dalam negeri, karena pada saat yang bersamaan banyak petani lada di Vietnam, India, Malaysia dan Brazil yang juga berlomba menanam lada demi memperoleh keuntungan dari harga lada yang sedang tinggi.

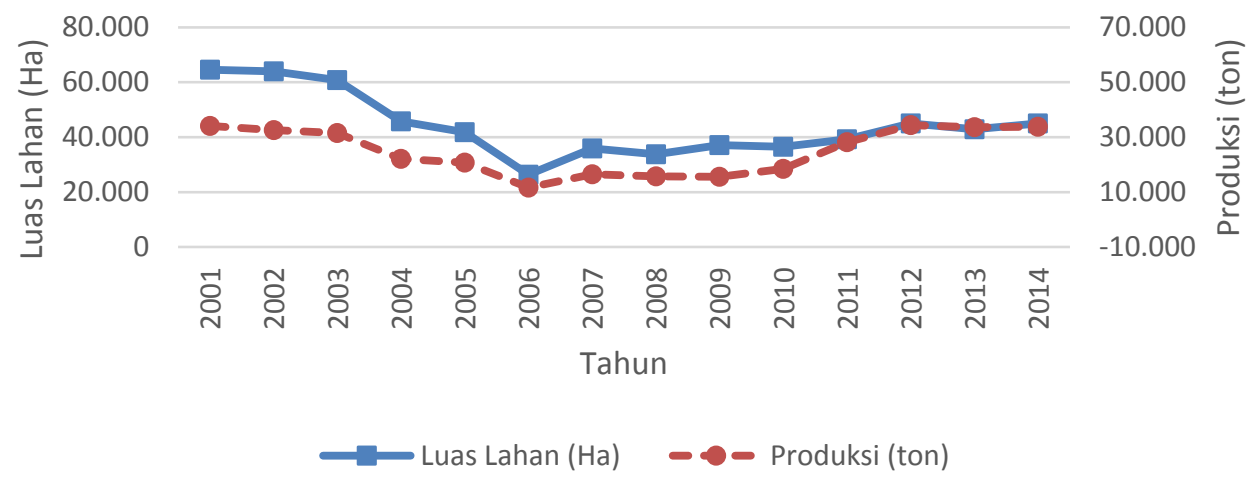

Gambar 1

Grafik Pengembangan Produksi dan Luas Lahan

Lada Putih di Provinsi Kepulauan Bangka Belitung

Sumber : Data diolah peneliti

\begin{abstract}
Menyikapi dinamika tersebut diperlukan suatu model perencanaan pengembangan kawasan pertanian berbasis komoditas unggulan perkebunan lada putih yang terintegrasi dan terpadu agar mampu mendorong akselerasi peningkatan produksi lada sebagai produk ekspor sekaligus diikuti peningkatan produksi nilai tambah hasil olahan pada sentra-sentra produksi dari sub-sektor perkebunan. Perencanaan
\end{abstract}

tersebut terangkum dalam Dokumen Masterplan dan Rencana Aksi Pengembangan Kawasan Perkebunan Berbasis Komoditas Lada di Provinsi Bangka Belitung.

Kebijakan Pengembangan Kawasan
Agropolitan
Kementerian Pertanian Republik
Indonesia telah menetapkan salah satu
kebijakan operasional pembangunan 
Jurnal Administrasi Negara

ISSN : 2598-4039 (Online)

ISSN : 2302-2231 (Print)
Rully Redhiani, Bambang Ari Satria,

Sekolah Tinggi Ilmu Sosial dan Ilmu Politik

Pahlawan 12 Sungailiat pertanian melalui pendekatan kawasan, sebagaimana dituangkan dalam Permentan Nomor 50 Tahun 2012 tentang Pedoman Pengembangan Kawasan Pertanian, dan Kepmentan Nomor 46 Tahun 2015 tentang Penetapan Lokasi Kawasan Perkebunan Nasional.

Berdasarkan Permentan Nomor 50 Tahun 2012, secara garis besar implementasi pengembangan kawasan pertanian dapat dibagi kedalam tahap: perencanaan, pelaksanaan dan pelaporan dengan urutan tahapan sebagai berikut: 1) pembentukan organisasi pelaksana, 2) penentuan komoditas, 3) penentuan lokasi kawasan kabupaten/kota, 4) penyusunan Masterplan pengembangan kawasan, 5) penyusunan rencana aksi pengembangan kawasan, 6) rencana pengembangan kawasan lingkup provinsi, 7) sinkronisasi rencana pengembangan kawasan lingkup Eselon I Kementerian Pertanian RI, 8) pelaksanaan kegiatan pengembangan kawasan, 9) monev dan pelaporan, dan 10) penyusunan database pengembangan kawasan.

Agar tercapai kesatuan pemahaman dalam mewujudkan kawasan perkebunan berbasis komoditas unggulan Lada, maka diperlukan satu cara pandang yang sama terhadap masa depan kawasan yang dituangkan ke dalam sebuah visi.
Adapun visinya adalah: Terwujudnya kawasan pertanian lada berkualitas tinggi terpadu yang berteknologi modern dan bersinergi secara kelembagaan dari hulu ke hilir serta berorientasi pasar lokal dan internasional.

Visi di atas memiliki makna bagaimana mewujudkan sebuah kawasan pertanian dengan basis Lada di Provinsi Bangka Belitung, yang dikelola oleh masyarakat setempat dengan dukungan teknologi modern untuk meningkatkan daya saing produk secara global, strategi pemasaran yang terarah serta didukung oleh kelembagaan di tingkat petani, daerah, mitra petani hingga pusat melalui kebijakan serta perlindungannya.

Mencermati Visi Pengembangan Kawasan Perkebunan Dengan Basis Lada tersebut di atas, maka perlu dijabarkan lebih lanjut dalam misi-misi sebagai langkah-langkah operasional untuk mencapai visi sebagai berikut.

1. Menjadikan kawasan pertanian sebagai pusat bisnis kolektif masyarakat berbasis Lada.

2. Menghasilkan produk pertanian berkualitas tinggi yang mampu bersaing di pasar internasional melalui penerapan teknologi modern dan efektif.

3. Mensinergikan antar kelembagaan dari tingkat petani, daerah hingga pusat.

Melihat misi-misi tersebut diatas, 
Jurnal Administrasi Negara

ISSN : 2598-4039 (Online)

ISSN : 2302-2231 (Print)
Rully Redhiani, Bambang Ari Satria,

Sekolah Tinggi Ilmu Sosial dan Ilmu Politik

Pahlawan 12 Sungailiat maka dirumuskan beberapa program prioritas untuk dapat menjawab dan menjabarkan apa yang menjadi target dari masing- masing misi. Adapun program program prioritas dimaksud adalah sebagai berikut.

1. Program penguatan sumber daya

2. Program peningkatan serta standarisasi kualitas produk
3. Program penguatan proses internal usaha

4. Program penguatan sistem pemasaran

5. Program penumbuhan investasi dan pangsa pasar

6. Program pengembangan serta perluasan pasar ekspor

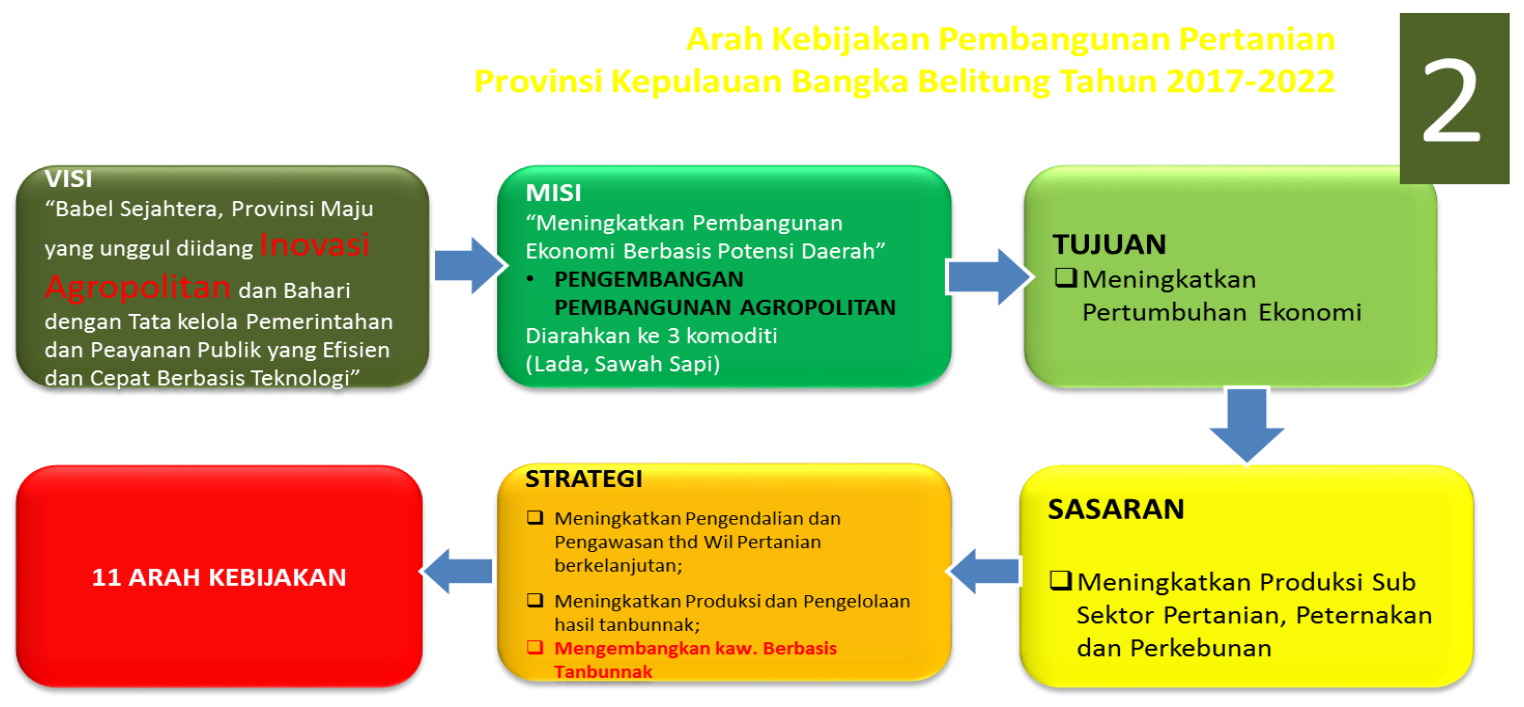

Gambar 2

Arah Kebijakan Pembangunan Pertanian Provinsi Kepulauan Bangka Belitung Tahun 2017-2022

Sumber : Pemerintah Provinsi Kepulauan Bangka Belitung

Berdasarkan skema tersebut diatas, 11 arah kebijakan yang telah disusun oleh Pemerintah Kepulaun Bangka Belitung upaya pembangunan kawasan pertanian di Provinsi Kepulauan Bangka Belitung.

1. Penyusunan kebijakan dan implementasi perlindungan lahan pertanian berkelanjutan.

2. Peningkatan sarana dan prasarana dan nilai tambah serta produksi pertanian, perkebunan, peternakan.

3. Pengembangan standarisasi SDM dalam meningkatkan daya saing sektor pertanian.

4. Pembinaan hubungan industri sektor pertanian

5. Peningkatan standarisasi produk dan jasa Koperasi Usaha Kecil dan Menengah (KUKM) dalam 
Jurnal Administrasi Negara

ISSN : 2598-4039 (Online)

ISSN : 2302-2231 (Print)
Rully Redhiani, Bambang Ari Satria,

Sekolah Tinggi Ilmu Sosial dan Ilmu Politik

Pahlawan 12 Sungailiat meningkatkan daya saing sektor pertanian.

6. Pengembangan produk pertanian, serta mendorong sinkronisasi antar stakeholder.

7. Meningkatkan pemberdayaan masyarakat di bidang pertanian.

8. Pengembangan KPB Batu Betumpang.

9. Pengembangan KTM Gantung.

10. Pengembangan kawasan Agropolitan dan Thecnopark Lada Air Gegas.

11. Pengembangan Kawasan Budidaya Pertanian.

\section{Implementasi Kebijakan Program} Agropolitan di Provinsi Kepulauan Bangka Belitung

Implementasi

kebijakan

merupakan tahap penting dalam proses suatu kebijakan publik. Implementasi kebijakan perlu dilakukan karena untuk melihat sejauh mana kebijakan publik tersebut dilaksanakan. Untuk mengetahui gambaran mengenai implementasi kebijakan program agropolitan Kepulauan Bangka Belitung, peneliti menggunakan teori implementasi kebijakan George Charles Edward III. Menurut Edward (dalam Sahya Anggara, 2014), implementasi diartikan sebagai tahapan dalam proses kebijaksanaan, yang berada diantara tahapan penyusunan kebijaksanaan dan hasil atau konsekuensi yang ditimbulkan oleh kebijaksanaan (output, outcome).

Menurut pandangan Edward III dalam Subarsono (2012) implementasi kebijakan dipengaruhi oleh empat variabel, yaitu : komunikasi, sumber daya, disposisi dan struktur birokrasi.

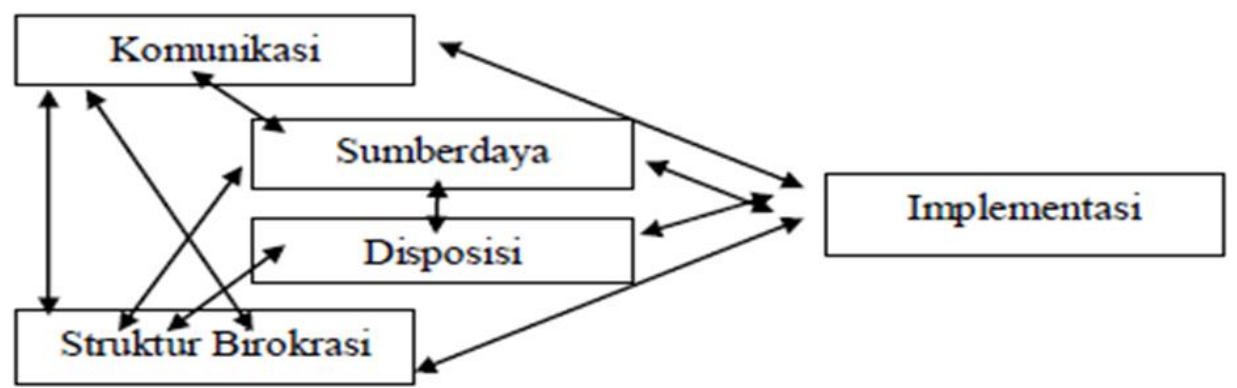

Gambar 3

Implementasi Kebijakan Menurut Edward III

Sumber : Implementasi Kebijakan Edward III (Dwiyanto Indiahono, 2017

a. Komunikasi

Komunikasi merupakan faktor penting dan berpengaruh dalam terciptanya suatu efisiensi kerja. Adanya komunikasi menunjukkan bahwa setiap kebijakan akan dapat dilakukan dengan baik jika terjadi komunikasi efektif antara pelaksana program (kebijakan) 
Jurnal Administrasi Negara

ISSN : 2598-4039 (Online)

ISSN : 2302-2231 (Print)
Rully Redhiani, Bambang Ari Satria,

Sekolah Tinggi Ilmu Sosial dan Ilmu Politik

Pahlawan 12 Sungailiat dengam kelompok sasaran (target group). Tujuan dan sasaran kebijakan dapat disosialisasikan secara baik sehingga dapat menghindari distorsi atas kebijakan dan program (Dwiyanto Indiahono, 2017). Ini menjadi penting karena semakin tinggi pengetahuan kelompok sasaran atas program maka akan mengurangi tingkat penolakan dan kekeliruan dalam melaksanakan atau mengimplementasikan kebijakan dalam ranah sesungguhnya. Dalam variabel komunikasi terdapat $3 \mathrm{sub}$ variabel yaitu:
1) Transmisi

Tranmisi merupakan suatu proses penyampaian informasi antara pihak satu dengan pihak yang lain. Penyampaian informasi ini tidak hanya antar pelaksana melainkan kepada kelompok sasaran (Siska Wulan Yuni, 2016).

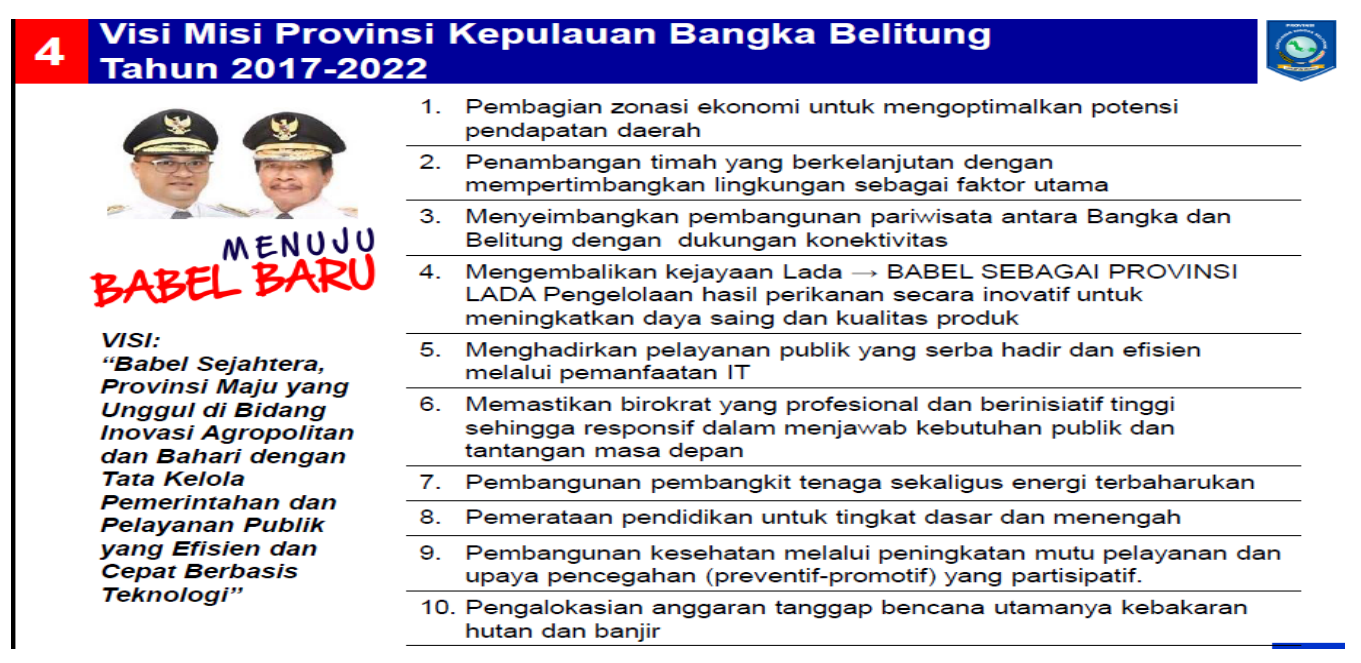

Gambar 4

Visi Misi Provinsi Kepulauan Bangka Belitung Tahun 2017-2022

Proses transmisi disampaikan dimana salah satu program yang langsung oleh Gubernur Provinsi diunggulkan adalah program Kepulauan Bangka Belitung Bapak Dr. H. agropolitan. Program agropolitan yang Erzaldi Rosman Djohan, SE, MM dalam sosialisasi "Arah dan Kebijakan Pembangunan Provinsi Kepulauan Babel (Dinamika, Tantangan dan Strategi)", disampaikan adalah sebagai berikut :

a. Memperluas lahan produksi lada di Bangka Belitung dalam rangka mengembalikan lada sebagai produk 
Jurnal Administrasi Negara

ISSN : 2598-4039 (Online)

ISSN : 2302-2231 (Print)
Rully Redhiani, Bambang Ari Satria,

Sekolah Tinggi Ilmu Sosial dan Ilmu Politik Pahlawan 12 Sungailiat agrobisnis andalan Bangka Belitung sehingga kejayaan Babel sebagai Provinsi lada bisa dicapai kembali.

b. Membangun pusat penelitian dan pengembangan rekayasa lada maupun produk perkebunan lainnya seperti karet dan sawit di Provinsi Bangka Belitung.

c. Memberikan pelatihan agrobisnis profesional kepada petani-petani di Bangka Belitung sehingga petani mampu memproduksi produk pertanian (khususnya lada) dengan kualitas unggul.

d. Memberikan bantuan bibit dan sarana pendukung pengembangan agrobisnis lainnya agar petani memperoleh hasil optimal.

2) Kejelasan

Kejelasan merupakan sub indikator yang lebih mengarah pada sejauh mana informasi yang disampaikan oleh pelaksana kepada pihak lain secara jelas sehingga memberikan pemahaman kepada penerima informasi (Siska Wulan Yuni, 2016). Kejelasan dari program agropolitan di Provinsi Kepulauan Bangka Belitung ini terlihat adanya pelatihan untuk para petani yang dilakukan oleh Pemerintah Provinsi Kepulauan Bangka Belitung berupa pelatihan teknis untuk 3000 petani setiap tahunnya. Pelatihan teknis juga dibantu oleh Balai Penyuluhan Sumber Daya Manusia (SDM)
Lampung serta pelatihan manajemen kelembagaan melalui pembentukan Lembaga Ekonomi Masyarakat.

3) Konsistensi

Faktor selanjutnya yang mempengaruhi komunikasi kebijakan ialah dimensi konsistensi. Jika implementasi kebijakan ingin berlangsung efektif, maka perintahperintah implementasi kebijakan pelaksana harus konsisten dan jelas. pelaksanaan program agropolitan cukup memiliki konsistensi dalam dalam pelaksanaanya.

Hal-hal yang telah dilaksanakan dalam pengembangan lada sebagai komoditas unggulan program agropolitan:

a. Telah disusunnya SOP Lada Unggul kerjasama dengan UGM melalui Pendekatan Pengendalian Biologi dan Organik.

b. Pemerintah Provinsi telah menerapkan Sistem Resi Gudang Komoditas Lada.

c. Penyediaan Tajar Hidup, Pupuk Organik, Agen Pengendalian Hayati dan Bimtek Petani.

d. Inisiasi penyusunan SOP lada melalui pendekatan agen, pengendali hayati dan organik yang ramah lingkungan.

e. Pemerintah Provinsi telah melakukan kerjasama pada berbagai stakeholder seperti BPTP, UGM. IPB, UNPAD dan UBB. 
Jurnal Administrasi Negara

ISSN : 2598-4039 (Online)

ISSN : 2302-2231 (Print)
Rully Redhiani, Bambang Ari Satria,

Sekolah Tinggi Ilmu Sosial dan Ilmu Politik Pahlawan 12 Sungailiat
Selain hal-hal yang telah dilaksanakan oleh Pemerintah Provinsi Kepulauan Bangka Belitung juga sudah menyusun rencana kedepan terkait pengembangan lada, yaitu :

a. Rehabilitasi dan perluasan lahan seluas 5000 ha (6 juta bibit) dan pembangunan Agro Technopark Lada.

b. Pembanguna Instalasi Pembibitan Lada Unggul, Agen Pengendali Hayati, Pupuk Organik Spesiifi (Lada), Pengolahan Pasca Panen dan Pembangunan Pusat Pelatihan dan Pendidikan Pengembangan Lada.

c. Penyediaan prasarana dan sarana pengairan pada kawasan perkebunan lada serta pengembangan model kawasan pertanian berbasis komodita lada.

\section{b. Sumber Daya}

Keberhasilan proses implementasi juga dipengaruhi oleh kemampuan memanfaatkan sumber daya yang ada.
Keberhasilan implementasi harus didukung oleh sumber daya yang memadai.

1) Sumber Daya Manusia

Sumber daya manusia adalah kecukupan baik kualitas maupun kuantitas implementor yang dapat melingkupi seluruh kelompok sasaran (Dwiyanto Indiahono, 2017). Interaksi multi pemangku kepentingan dan pelaku dalam sistem rantai nilai komoditas lada melibatkan banyak pihak, mulai dari pelaku usaha (petani, APLI, pedagang, eksportir, dan AELI), pemerintah (Dinas Perkebunan, Dinas Perindustrian, Dinas Perdagangan, Badan Pelaksana Penyuluhan, Badan Pengkajian Teknologi Pertanian/BPTP, Badan Pertanahan, Dinas Koperasi dan UMKM, Bappeda) dan Perguruan Tinggi sebagai sumber ilmu dan pengetahuan. Berbagai pelaku dan pemangku kepentingan dalam sistem komoditas lada putih diharapkan dapat saling berinteraksi dan bersinergi dalam meningkatkan produksi dan pendapatan petani lada. 
Jurnal Administrasi Negara

ISSN : 2598-4039 (Online)

ISSN : 2302-2231 (Print)
Rully Redhiani, Bambang Ari Satria,

Sekolah Tinggi Ilmu Sosial dan Ilmu Politik

Pahlawan 12 Sungailiat

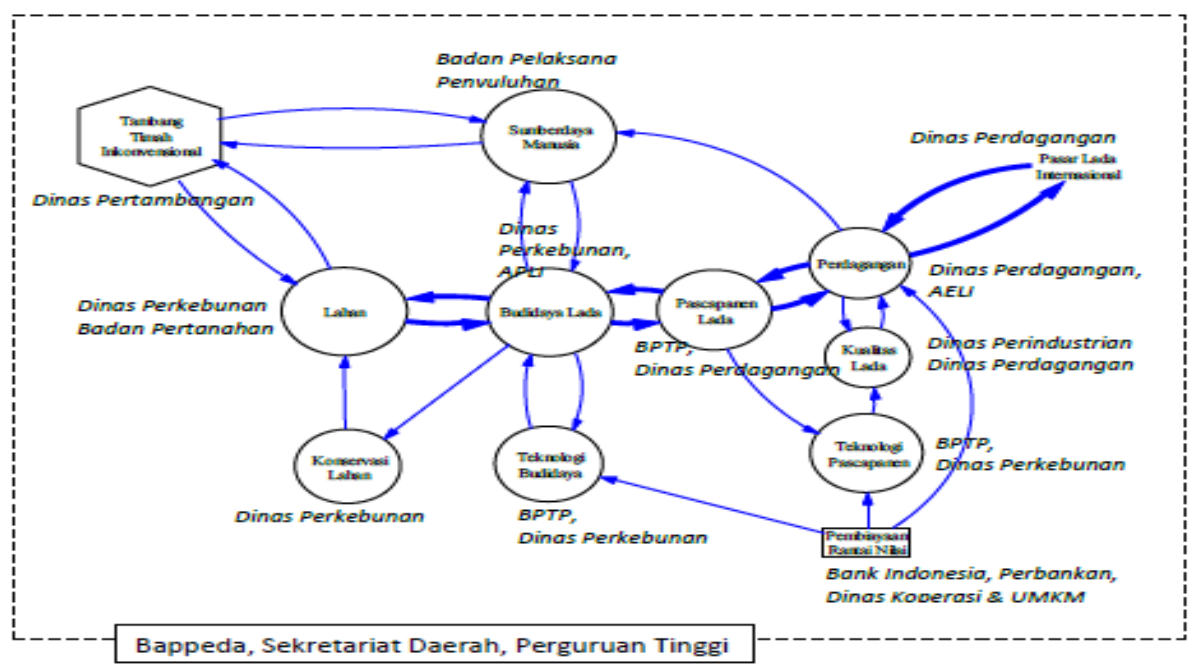

Gambar 5

Interaksi Antar Pelaku dan Pemangku Kepentingan

Sistem Komoditas Lada di Bangka Belitung.

Sumber : Pemerintah Provinsi Kepulauan Bangka Belitung

2) Sumber Daya Anggaran

Sumber daya anggaran atau finansial adalah kecukupan modal investasi atas sebuah program/kebijakan (Dwiyanto Indiahono, 2017). Sumber daya anggaran memiliki peran yang cukup penting dalam pelaksanaan program agropolitan di Provinsi Kepulauan Bangka Belitung. Anggaran yang digunakan berasal dari Anggaran Pendapatan Belanja Negara (APBN) dan Anggaran Pendapatan Belanja Daerah (APBD).

3) Sumber Daya Peralatan

Peralatan yang ada saat ini masih belum cukup sehingga berdampak pada kegiatan hanya sebetas peralatan tradisonal. Belum adanya sarana dan prasarana pengairan pada kawasan pertanian lada, mengingat kawasan mengingat daerah agropolitan harus memiliki kondisi fisik yang bagus.

4) Informasi dan Kewenangan

Sumber daya informasi dan kewenangan sangat dibtuhkan dalam menjalankan suatu kebijakan. Dalam hal ini proses pelaksanaan penyampaian informasi berjalan dengan baik informasi yang didapat oleh petani melalui rapat maupun diskusi dianggap cukup banyak dan beberapa kali disampaikan sehingga mereka cukup mengerti mengenai program agropolitan namun hal tersebut tidak terjadi pada seluruh 
Jurnal Administrasi Negara

ISSN : 2598-4039 (Online)

ISSN : 2302-2231 (Print)
Rully Redhiani, Bambang Ari Satria,

Sekolah Tinggi Ilmu Sosial dan Ilmu Politik

Pahlawan 12 Sungailiat petani hanya sebagian petani saja yang mengerti mengenai program tersebut.

Sedangkan untuk kewenangan pemerintah provinsi sangat menggunakannya dengan baik namun hak tersebut berbeda dengan pelaksana teknis, mereka jarang menggunakan sumber daya kewenangan untuk mengatur jalannya program agropolitan di Provinsi Kepulauan Bangka Belitung.

\section{c. Disposisi}

Disposisi adalah variabel berikutnya yang mempengaruhi implementasi kebijakan publik. Menurut Wahab dalam A. Ramadhani (2017) disposisi adalah watak dan karakteristik yang dimiliki oleh pelaksana kebijakan, seperti komitmen, disiplin, kejujuran, kecerdasan, dan sifat demokratis.

1) Pengangkatan Birokrasi

Penempatan pelaksana/aparatur pada jabatan tertentu, harus memiliki kompetensi dan dedikasi yang baik terhadap pelaksananaan kebijakan yang sudah ditetapkan sehingga implementasi dari kebijakan dapat tercapai secara maksimal. Sebaliknya apabila disposisi atau pengangkatan pelaksana/aparatur yang tidak sesuai dapat menjadi masalah pada implementasi kebijkan karena pelaksana tersebut tidak dapat melaksanakan kebijakan yang telah ditetapkan. Kondisi ini telah menjadi perhatian Pemerintah Provinsi Kepulauan Bangka Belitung dengan menempatkan pelaksana/aparatur yang sudah memiliki kompetensi dan dedikasi yang baik dalam melaksanakan implementasi kebijakan, khususnya yang memiliki latar belakang pendidikan pertanian serta keterampilan di bidang tersebut. Untuk aparatur yang menduduki jabatan struktural sebagai pengambil kebijakan adalah aparatur yang sudah lama berkecimpung di sektor pertanian demikian juga yang menduduki jabatan fungsional sudah sering mengikuti pelatihan-pelatihan teknis di bidang pertanian sebagai upaya untuk meningkatkan kompetensi.

2) Insentif

Sikap pelaksana kebijakan dapat menjadi faktor penentu dalam keberhasilan implementasi kebijakan. Sehingga perlu dilakukan upaya atau suatu teknik tertentu yang mendorong para pelaksana kebijakan dapat bersikap dan melaksanakan perintah dengan baik. Faktor berikutnya dari disposisi yang dapat mempengaruhi sikap para pelaksana adalah insentif. Dengan memanipulasi insentif seperti memberikan biaya tambahan atau biaya tertentu akan menjadi faktor pendorong dalam pelaksanaan kebijakan. Upaya pemberian insentif 
Jurnal Administrasi Negara

ISSN : 2598-4039 (Online)

ISSN : 2302-2231 (Print)
Rully Redhiani, Bambang Ari Satria,

Sekolah Tinggi Ilmu Sosial dan Ilmu Politik

Pahlawan 12 Sungailiat

ini telah dilaksanakan oleh pemerintah Provinsi Kepulauan Bangka Belitung agar pelaksanaan implementasi kebijakan di bidang pertanian dapat terlaksana secara maksimal. Insentif yang diberikan dapat berupa tunjangan jabatan dan honorarium terkait pelaksanaan program serta tambahan biaya operasional yang sudah disiapkan melalui mekanisme penganggaran APBD dan APBN.

\section{d. Struktur Birokrasi}

Struktur birokrasi adalah membahas badan pelaksana suatu kebijakan, tidak dapat dilepaskan dari struktur birokrasi. Struktur birokrasi adalah karakteristik, norma-norma, dan pola-pola hubungan yang terjadi berulang-ulang dalam badan-badan eksekutif yang mempunyai hubungan baik potensial maupun nyata dengan apa yang mereka miliki dalam menjalankan kebijakan.

Pelaksana kebijakan mungkin mengetahui apa yang harus dilakukan dan memiliki sumber daya yang memadai, namun tidak menutup kemungkinan hal tersebut masih menghalangi proses implementasi karena struktur organisasi yang dimiliki.

1) Standart Operational Procedure (SOP)

Standard

Procedure (SOP)

Operational merupakan

perkembangan dari tuntutan internal akan kepastian waktu, sumber daya serta kebutuhan penyeragaman dalam organisasi kerja yang kompleks dan luas (Winarno dalam D. R. Apriyanty, 2016). Dalam SOP diatur waktu dan alur kegiatan yang harus dilaksanakan sehingga waktu yang tersedia dapat dioptimalkan sebaik mungkin dan tindakan para pejabat yang terlibat dapat diseragamkan serta adanya kesamaan dalam penerapan peraturan yang berlaku. Ketersediaan SOP dalam melaksanakan kebijakan di Provinsi Kepulauan Bangka Belitung secara keseluruhan sudah ada khususnya SOP di bidang pertanian, namun demikian belum seluruhnya dapat dilaksanakan dan dipahami. Sebagai contoh SOP budidaya lada dan SOP Pasca Panen yang sudah ada ternyata tidak semua PPL dan Petani dapat memahaminya sehingga pelaksanaan SOP tersebut belum optimal.

2) Fragmentasi

Fragmentasi merupakan unsur kedua dalam variable struktur organisasi yang dapat mempengaruhi implemtasi kebijakan. Fragmentasi dalam implementasi kebijakan adalah dengan melakukan penyebaran tanggung jawab pelaksanaan kebijakan kepada unit organisasi lainnya. Dengan adanya beberapa unit organisasi dalam melaksanakan suatu kebijakan maka diperlukan koordinasi yang baik. Tanpa adanya koordinasi yang baik dapat terjadi masalah dan hambatan seperti 
Jurnal Administrasi Negara

ISSN : 2598-4039 (Online)

ISSN : 2302-2231 (Print)
Rully Redhiani, Bambang Ari Satria,

Sekolah Tinggi Ilmu Sosial dan Ilmu Politik

Pahlawan 12 Sungailiat

penggunaan sumberdaya dan pelaksanaan kewenangan tiap unit organisasi yang terlibat.

\section{PENUTUP}

\section{Simpulan}

Keberhasilan

implementasi

kebijakan pemerintah dalam bidang tertentu dapat menjadi tolak ukur keberhasilan suatu pemerintahan dalam pencapaian Visi dan Misinya. Visi Pemerintahan Provinsi Kepulauan Bangka Belitung yaitu "Babel Sejahtera, Provinsi Maju yang Unggul di Bidang Inovasi Agropolitan dan Bahari dengan Tata Kelola Pemerintahan dan Pelayanan Publik yang Efisien dan Cepat Berbasis Teknologi". Dan Misi "Meningkatkan Pembangunan Ekonomi Daerah" dengan Pengembangan

Pembangunan Agropolitan Dapat menjadi milestone pelaksanaan program-program agropolitan di Provinsi Kepulauan Bangka Belitung.

Implementasi

agropolitan di Provinsi Kepulauan Bangka Belitung dapat dikatakan berjalan dengan baik, karena selain menjadi salah satu fokus pembangunan dalam Visi dan Misi Pemerintahan, tetapi juga didukung oleh faktor-faktor pendukung.Faktor pertama yaitu adanya proses komunikasi yang baik antara unsur pemerintahan dan publik, antara Gubernur dan Organisasi Perangkat Daerah (OPD) serta antara OPD yang bertanggung jawab dibidang pertanian dengan masyarakat khususnya para petani. Faktor kedua adalah Sumberdaya yang ada, seperti Sumber Daya Manusia, Sumber Daya Anggaran/Finasial, Sumber Daya Peralatan, dan Sumber Daya Informasi. Dari kondisi dilapangan diketahui bahwa Provinsi Kepulauan Bangka Belitung sangat didukug oleh sumberdayasumberdaya tersebut sehingga dapat mendukung tercapainya implementasi kebijakan program agropolitan. Faktor ketiga adalah Disposisi yang merupakan komitmen pelaksana kebijakan. Implementasi Kebijakan Program Agropolitan sudah didukung oleh aparatur yang memiliki kompetensi dan latar belakang di bidang pertanian yang tersebar di OPD yang menangani kebijakan pertanian. Selain itu pemerintah provinsi juga sudah memberikan dukungan penuh dengan kebijakanpemberian biaya tertentu bagi pelaksana kebijakan. Faktor pendukung keempat adalah Struktur Birokrasi. Dari kondisi yang ada perlu dilakukan evaluasi terhadapa unsur yang menjadi fokus dalam struktur birokrasi sehingga pelaksanaan peraturan dan kebijakan yang diambil dapat seragam dan sesuai dengan kebijakan yang telah ditetapkan dalam Standar Operasional Prosedur.

Pelaksanaan Program Kebijakan Agropolitan melibatkan banyak stakeholder, sehingga koordinasi menjadi suatu yang penting dalam 
Jurnal Administrasi Negara

ISSN : 2598-4039 (Online)

ISSN : 2302-2231 (Print)
Rully Redhiani, Bambang Ari Satria,

Sekolah Tinggi Ilmu Sosial dan Ilmu Politik

Pahlawan 12 Sungailiat implementasi program tersebut. Dari kondisi dilapangan dan pernyataan yang diberikan, menunjukkan bahwa koordinasi sudah dilaksanakan dengan baik terhadap seluruh stakeholder, mulai dari tingkat kementerian, dinas provinsi, dinas kabupaten, aparat desa, PPL, sampai kepada kelompok tani dan petani. Dengan komitmen yang baik serta memperhatikan faktor-faktor pendukung yang telah diuraikan maka pencapaian implementasi kebijakan program agropolitan di Provinsi Kepulauan Bangka Belitung dapat terlaksana dengan baik.

\section{Saran}

Implementasi kebijakan program agropolitan di Provinsi Kepulauan Bangka Belitung dapat berhasil dengan baik apabila adanya komitmen bersama seluruh pemangku kepentingan serta memperhatikan faktor-faktor pendukung implementasi. Salah satu yang harus menjadi perhatian pemerintah provinsi dan dinas terkait adalah memberikan pemahaman kepada aparatur pelaksana dan para petani agar dapat mengikuti tahapantahapan program dengan menerapkan Standar Operasional Prosedur (SOP) yag ada. Maka perlu dilakukan sosialisasi, workshop ataupun pelatihan-pelatihan penerapan SOP yang benar.

\section{Referensi}

Akib, Haedar. 2010. Implementasi Kebijakan, Apa, Mengapa dan Bagaimana. Jurnal Administrasi Publik, Volume 1 No. 1 Thn. 2010

Anggara, S. 2018. Kebijakan Publik. Edisi ke-2. CV. Pustaka Setia. Bandung.

Aprianty, D. R. (2016). Penerapan Kebijakan E-Government Dalam Peningkatan Mutu Pelayanan Publik Di Kantor Kecamatan Sambutan Kota Samarinda. Jurnal Ilmu Pemerintahan, 4(4).

Baiq Diana, dkk. 2016. Implementasi Program Pengembangan Kawasan Agropolitan Sembalun Kabupaten Lombok Timur. Jurnal Pembangunan dan Alam Lestari. Vol. 7 Nomor 2.

Basuki, A. T. (2012). Pengembangan kawasan agropolitan. Jurnal Ekonomi $\mathcal{E}$ Studi Pembangunan, 13(1), 53-71.

Farhanah, L., \& Prajanti., S.D.W. (2015). Strategies in Developing Agropolitan Areas in Indonesia. Jurnal Ekonomi Pembangunan. 16(2), 158-165.

Indiahono, D. 2016. Kebijakan Publik

Berbasis Dynamic Policy Analisys. Gava Media, Yogyakarta.

Keputusan Menteri Pertaniaan Nomor 46 Tahun 2015, tentang Penetapan Lokasi Kawasan Perkebunan Nasional

Kusumanegara, S. 2010. Model dan Aktor Dalam Proses Kebijakan Publik. Gava Media, Yogyakarta. 
Jurnal Administrasi Negara

ISSN : 2598-4039 (Online)

ISSN : 2302-2231 (Print)
Rully Redhiani, Bambang Ari Satria,

Sekolah Tinggi Ilmu Sosial dan Ilmu Politik Pahlawan 12 Sungailiat
Mahardian, Ardhana Januar, 2013, Implementasi Kebijakan Agropolitan di Kabupaten Tulungagung, Surabaya

Nugroho, Iwan. 2009. Agropolitan: Suatu Kerangka Berpikir Baru Dalam Pembangunan Nasional?. Jurnal of Indonesian Applied Economics. Volume 2 Nomor 2.

Peraturan Menteri Pertanian Nomor 50 Tahun 2012 tentang Pedoman Kawasan Pertanian

Putra, R. N. (2015). Implementasi kebijakan pengendalian alih fungsi lahan pertanian di kota batu sebagai kawasan agropolitan. Kebijakan dan Manajemen Publik, 3(2), 71-80.

Ramadhani, A. dan M.A.Ramadhani.
(2017). Konsep Umum Pelaksanaan Kebijakan Publik. Jurnal Publik. 11 (1). 1-12.

Subarsono, A.G. 2012. Analisis Kebijakan Publik : Konsep, Teori, dan Aplikasi. Pustaka Pelajar, Yogyakarta, Indonesia

Sugiyono. 2012. Metode Penelitian Kuantitatif, Kualitatif, dan Kombinasi (Mixed methods). CV Alfabeta, Bandung

Wulan Yuni, S. I. S. K. A. (2016). Implementasi Kebijakan Pengembangan Kawasan Agropolitan Di Desa Ringinrejo Kecamatan Kalitidu Kabupaten Bojonegoro. Publika, 4(7). 